\title{
THE RELATIONSHIP BETWEEN NON-RENEWABLE ENERGY CONSUMPTION AND ECONOMIC GROWTH: A REGIONAL ANALYSIS OF EUROPEAN CONTINENT
}

\author{
Yenilenemeyen Enerji Tüketimi ile Ekonomik Büyüme Arasındaki İlişki: \\ Avrupa Kitasının Bölgesel Analizi
}

\author{
Metehan YILGÖR*, Suna KORKMAZ ${ }^{* *}$ \& Fulden KÖMÜRYAKAN***
}

\begin{abstract}
Keywords:

Non-renewable

Energy, Economic

Growth, European

Continent, Panel

Causality Analysis.

JEL Codes:

O13, O47, C23

Anahtar Kelimeler:

Yenilenemeyen Enerji,

Ekonomik Büyüme,

Avrupa Kitasi, Panel

Nedensellik Analizi.

JEL Kodları:

O13, O47, C23

This study aims to examine the relationship between the non-renewable energy consumption of the countries and their economic status since energy consumption and production appear to be interconnected phenomena. This study analyses the Eastern, Middle, North, South, and Western regions of the European continent from 1990 to 2014. To the best of our knowledge, this is the first paper to analyze the relationship between non-renewable energy consumption and economic growth in the European continent by region. The study adopts a panel causality process to examine the relationship between two phenomena. According to the empirical analyses, there is bidirectional causality between non-renewable energy consumption and economic growth in Eastern, Middle, North, and South European regions whereas a unidirectional relationship from non-renewable energy consumption to economic growth in the Western. Non-renewable energy consumption and economic growth are still interconnected phenomena in the European countries even though climate concerns, environmental precautions, and promotion to reduce unsustainable production.

Öz

Yenilenemeyen enerji tüketimi ve ülkelerin ekonomik durumları birbirine bağlı olgular olarak ele alınmaktadır. $\mathrm{Bu}$ nedenle bu çalışma, ülkelerin yenilenemeyen enerji tüketimi ve ekonomik büyümeleri arasındaki ilişkiyi incelemeyi amaçlamaktadır. Bu çalışma, Avrupa kıtasının Doğu, Orta, Kuzey, Güney ve Batı bölgelerini, 1990 ve 2014 dönemleri arasında analiz etmektedir. Bildiğimiz kadarıyla bu çalışma, yenilenemeyen enerji tüketimi ile ekonomik büyüme arasındaki ilişkiyi, Avrupa kıtasındaki bölgelere göre analiz eden ilk çalışmadır. Bu çalışma, yenilenemeyen enerji tüketimi ve ekonomik büyüme arasındaki ilişkiyi incelemek amacıyla panel nedensellik analizi yöntemini kullanmaktadır. Analiz sonuçlarına göre, Doğu, Orta, Kuzey ve Güney Avrupa bölgelerinde yenilenemeyen enerji tüketimi ile ekonomik büyüme arasında çift yönlü nedensellik olduğu belirlenirken, Batı Avrupa'da yenilenemeyen enerji tüketiminden ekonomik büyümeye doğru tek yönlü bir ilişki olduğu belirlenmiştir. Sonuç olarak, yenilenemeyen enerji tüketimi ve ekonomik büyümenin, ülkelerin iklim değişikliğine yönelik kaygıları, aldıkları çevresel önlemler ve sürdürülemez üretimi azaltmaya yönelik teşviklere rağmen Avrupa ülkelerinde hala birbiriyle bağlantılı olgular olduğu belirlenmiştir.
\end{abstract}

\footnotetext{
* Prof. Dr., Bandırma Onyedi Eylül University, Faculty of Economics and Administrative Sciences, Department of Econometrics, myilgor@bandirma.edu.tr, ORCID: 0000-0001-6921-6684 (Corresponding Author)

** Prof. Dr., Bandırma Onyedi Eylül University, Faculty of Economics and Administrative Sciences, Department of Economics, skorkmaz@bandirma.edu.tr, ORCID: 0000-0001-6221-2322

**** Research Assistant, Bandırma Onyedi Eylül University, Faculty of Economics and Administrative Sciences, Department of Econometrics, fkomuryakan@bandirma.edu.tr, ORCID: 0000-0002-4034-513X
}

Makale Geliş Tarihi (Received Date): 14.04.2021 Makale Kabul Tarihi (Accepted Date): 13.06.2021 


\section{Introduction}

Agriculture was at the center of the economies before the Industrial Revolution and societies have been dependent on the soil. However, the emergence of the steam engine and the use of steam as an energy resource in production were greatly advantageous and led to an increase in production with the Industrial Revolution. The use of such new technologies in the industry after the Industrial Revolution brought about an increase in mass production. Furthermore, the division of labor became more widespread with the use of such technologies in production and improved the productivity of employees.

The impact of energy consumption in everyday life, technology, and economic development increases significantly. Energy equates to work capacity; it comes in various forms, such as motional, heat, light, electrical, chemical, nuclear, and gravitational. The total energy is the sum of all forms of energy within a system (Demirel, 2012). Energy resources are classified as primary and secondary. Primary energy resources are non-renewable such as fossil fuels, coal, oil, natural gas, and nuclear energy, while secondary energy resources such as include solar power, biofuel, wind, and geothermal energy are renewable or waste products. Figure 1 illustrates the primary and secondary energy resources.

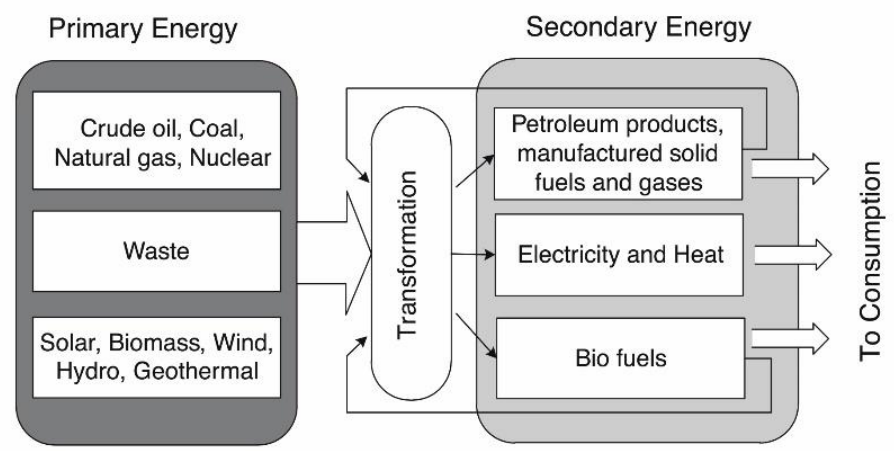

Figure 1. Types of Primary and Secondary Energies Source: Demirel, 2012.

According to the European Union, environmental quality is central to individuals' health and well-being as well as the economies of the countries. Therefore, in relatively recent years, countries have started considering environmental policies and legislation to promote businesses and firms to move toward a sustainable economy. Also, countries have started to acknowledge environmental agreements and protocols that cover sustainable production. The countries seek to ensure that promote low-carbon technologies and adaptation measures. Although climate concerns, environmental precautions, and promotion to reduce unsustainable production, nonrenewable energy resources are still consumed more than renewable energy resources to provide energy in most countries. Therefore, the sustainability of consuming non-renewable energy consumption and its effect on economic growth is one of the most examined topics in the literature.

This study aims to examine the relationship between the primary energy consumption of the countries and their economic status since energy use and production appear to be interconnected phenomena. In recent papers, continent- and region-wise analysis of energy 
consumption and economic growth attracts attention since the amount of energy consumption and the status of economic growth of countries differ by continents and regions. However, to the best of our knowledge, this is the first paper to analyze the relationship between non-renewable energy consumption and economic growth in the European continent by region. The European continent contains the countries that have some of the world's highest environmental standards and environmental policies as well as advanced industrialization and economies. Therefore, it is important to analyze and determine the relationship between non-renewable energy consumption and economic growth since the environmental policies and legislation takes attention to environmentally friendly energy resources instead of non-renewable energy.

This study examines the Eastern, Middle, North, South, and Western regions of the European continent over 1990 - 2014. The analysis of the relationship between primary energy consumption and the economic growth process of this study contains three steps. The first step covers the empirical analyses of the stationary level of the series with the first- and secondgeneration panel unit root tests. This step also covers the panel unit root tests with structural breaks in order to decide the stationary levels of the series since the panel data may contain structural breaks. The second step contains the determination of the homogeneity of the panel data in order to decide the further analysis method. Lastly, the third step examines the relationship between non-renewable energy consumption and economic growth region-wise by adopting the heterogeneous panel Granger causality analysis.

The next section covers the review of previous studies about energy consumption and economic growth. The dataset analysis section examines the descriptive statistics of the panel data. The methods and empirical results section explain the methodological issues and the results of the analyses. Lastly, the paper closes with the conclusion and discussion.

\section{Review of Previous Studies}

There is a wide literature about examining the relationship between non-renewable or renewable energy consumption and economic growth in various forms. A brief analysis of the papers that examine that relationship is below.

Asafu-Adjaye (2000) determined a unidirectional causal relationship from energy consumption to income for India and Indonesia, and a bidirectional causal relationship from energy consumption to income in Thailand and the Philippines in the short term. Paul and Bhattacharya (2004) found a bidirectional causal relationship between energy consumption and economic growth in India over the period 1950 - 1996. Mehrara (2007) examined 11 selected oil-exporting countries and found a unidirectional causal relationship from economic growth to energy consumption. Ang (2008) determined a causal relationship from economic growth to energy consumption for Malaysia over the period 1971 - 1999, in both the short and the long terms. Zhang and Cheng (2009) found a unidirectional causal relationship from economic growth to energy consumption for China over the period 1960 - 2007. Apergis and Payne (2009) investigated 6 Central American countries over the period 1980 - 2004 and found a causal relationship from energy consumption to economic growth, in both the short and the long terms. Ozturk, Aslan, and Kalyoncu (2010) performed a panel causality analysis for 51 countries over the period 1971 - 2005 and found a bidirectional causal relationship from economic growth to energy consumption for low-income countries and a bidirectional causal 
relationship between economic growth and energy consumption for middle-income countries. Fuinhas and Marques (2012) determined a bidirectional causal relationship between primary energy consumption and economic growth over the period 1965 - 2009 for Portugal, Italy, Greece, Spain, and Turkey in both the short and the long terms. Chaudhry, Sadfar, and Farooq (2012) concluded that electricity consumption stimulated economic growth more than other energy resources for Pakistan over the period 1972 - 2012. Adhikari and Chen (2013) explored 80 developing countries over the period $1990-2009$ and found a relationship from energy consumption to economic growth for upper-middle-income and low-income countries and from economic growth to energy consumption for low-income countries. Muse (2014) found a bidirectional causal relationship between total energy consumption and economic growth in the long term for Nigeria over the period 1980 - 2012. Pao, Li, and Fu (2014) determined a unidirectional causal relationship from energy consumption to economic growth in the short term for Brazil over the period 1980 - 2008. Dogan and Seker (2016) investigated the European Union over period 1980 - 2012 and determined unidirectional causality from real income to carbon emissions. Gozgor, Lau, and Lu (2018) examined 29 OECD countries over the period 1990 - 2013 and found that both renewable and non-renewable energy consumption were associated with higher economic growth. Akadiri and Akadiri (2020) analyzed the 5 Middle East Countries over the years 1975 - 2013 and determined unidirectional causality from CO2 emissions to income per capita. Cevik, Y1ldırım, and Dibooglu (2020) explored the renewable and non-renewable energy consumption and economic growth by adopting regime-dependent Granger causality analysis for the United States and provided evidence about a bidirectional causality non-renewable energy consumption and economic growth. However, the results indicate that there is no causality between renewable energy consumption and economic growth of the United States.

Some of the limited studies that examine the relationship between energy consumption and economic growth continent- and region-wise are briefly analyzed below.

$\mathrm{Yu}$ and Meng (2008) examined the relationship between energy consumption and economic growth in the Western and Eastern regions of China and found that the relationship between energy consumption and economic growth was closer in the eastern parts of the country compared to the western parts. Fatai (2014) analyzed 18 sub-Saharan African countries over the period 1980 - 2011 and found a unidirectional causal relationship from energy consumption to economic growth for Eastern and Southern Africa sub-regions. Khan, Yaseen, and Ali (2018) explored 24 lower middle-income countries from Asia, Europe, Africa, and America from 1990 to 2015 and determined that the causality results differ by the continents. Usman, Kousar, Yaseen and Makhdum (2020) investigated 33 upper-middle-income countries from four continents during the period from 1994 to 2017 and found that the causal connection varies by the continents. 


\section{Dataset Analysis}

This study focuses on the relationship between primary energy consumption and economic growth in regions of the European continent ${ }^{1}$. According to the United Nations, the European continent contains 50 countries with almost about $11 \%$ of the world population in the year 2018. European continent can be divided into 5 regions as Eastern, Middle, North, South, and Western. The panel data of the regions have been collected from the World Development Indicators of the World Bank database for the 35 countries over the period from 1990 to 2014. Eastern, Middle, North, South, Western regions of Europe continent contain 10, 5, 10, 16, and 9 countries, respectively. This study analysis 7 countries from the Eastern region ${ }^{2}, 3$ countries from the Middle region ${ }^{3}, 7$ countries from the North region ${ }^{4}, 9$ countries from the South region ${ }^{5}$, and 7 countries from the Western region ${ }^{6}$ due to lack of data availability ${ }^{7}$.

In order to analyze the primary energy consumption of the countries, the energy use $\mathrm{kg}$ of oil equivalent per capita data that refers to the use of energy before the transformation has been collected from the World Bank database. Since the Gross Domestic Product (GDP) represents the overall economic status and growth of the countries, GDP per capita has been collected that refers to GDP divided by midyear population are in constant 2010 United States dollars.

According to the literature on energy economics, the relationship between energy consumption and economic growth can be analyzed in a linear logarithmic form (Pao et al., 2014). Table 1 shows the descriptive statistics of energy consumption and GDP per capita in both forms.

Table 1. Descriptive Statistics of The Variables

\begin{tabular}{lccccc}
\hline Region & $\begin{array}{c}\text { Energy } \\
\text { Consumption }\end{array}$ & $\begin{array}{c}\text { Logarithmic } \\
\text { Energy } \\
\text { Consumption }\end{array}$ & $\begin{array}{c}\text { GDP per } \\
\text { capita }\end{array}$ & $\begin{array}{c}\text { Logarithmic } \\
\text { GDP per } \\
\text { capita }\end{array}$ & $\begin{array}{c}\text { No. of } \\
\text { Observations }\end{array}$ \\
\hline Eastern & $2,483.04$ & 7.65 & $4,553.93$ & 8.24 & 225 \\
Middle & $3,331.95$ & 8.08 & $15,095.11$ & 9.54 & 75 \\
North & $5,692.90$ & 8.53 & $48,166.71$ & 10.73 & 175 \\
South & $1,942.95$ & 7.47 & $18,591.47$ & 9.53 & 225 \\
Western & $4,806.05$ & 8.43 & $51,901.15$ & 10.79 & 175 \\
\hline
\end{tabular}

According to Table 1, the South region consumes the least primary energy whereas the North region consumes it the most. Table 1 also shows that the Eastern region has the least GDP per capita whereas the Western has it the most. The reason for these statements may be the economic development status of the countries along with industrialization. North and Western regions contain developed economies whereas the south and eastern regions contain mostly

\footnotetext{
${ }^{1}$ In this study, ethics of research and publication were followed and the study does not require any permission from the ethics committee and/or legal or special permission.

2 Armenia, Azerbaijan, Belarus, Bulgaria, Georgia, Kazakhstan, Romania, Russian Federation, and Ukraine.

${ }^{3}$ Czech Republic, Poland, and Slovenia.

${ }^{4}$ Denmark, Finland, Iceland, Ireland, Norway, Sweden, and United Kingdom.

${ }^{5}$ Albania, Cyprus, Greece, Italy, Malta, North Macedonia, Portugal, Spain, and Turkey.

${ }^{6}$ Austria, Belgium, France, Germany, Luxembourg, Netherlands, and Switzerland.

7 This study could not analyze Moldova, Hungary, Slovak Republic, Estonia, Latvia, Lithuania, Andorra, Montenegro, Kosovo, San Marino, Bosnia and Herzegovina, Croatia, Serbia, Liechtenstein, and Monaco.
} 
emerging economies. Along with the studies in the literature, it is expected that the emerging economies may have less energy consumption than developed economies since the industrialization may be less. Figure 2 and 3 shows the trends in logarithmic energy consumption and logarithmic GDP per capita by regions to determine the changes over years.

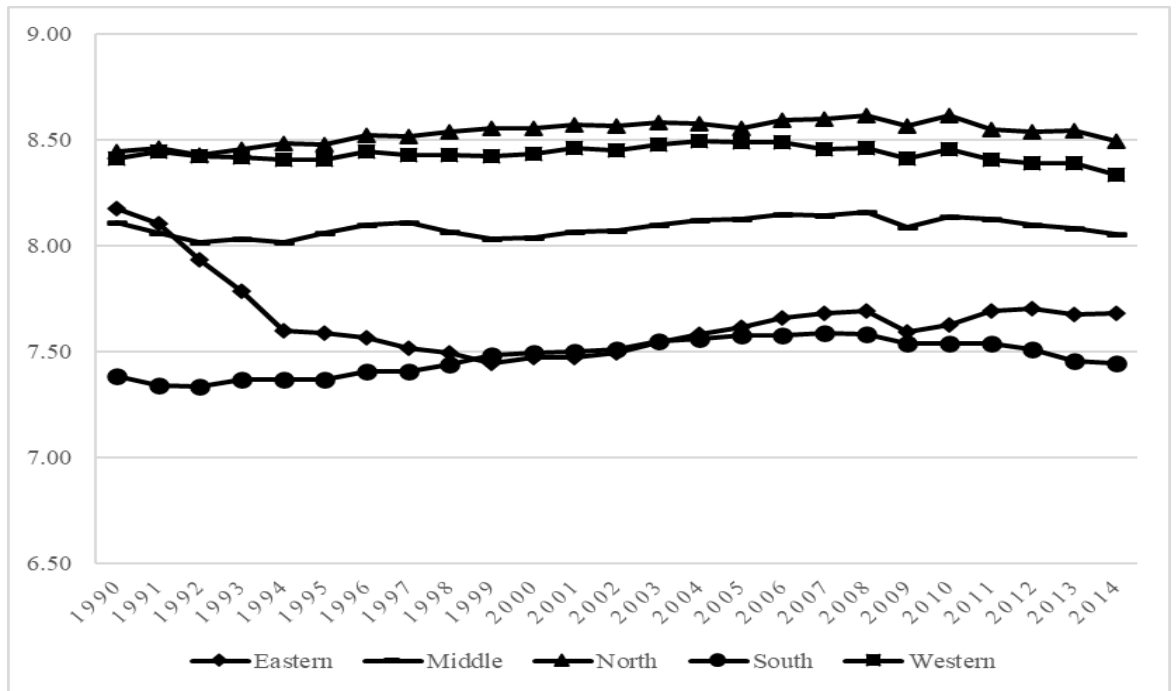

Figure 2. The Trend of Logarithmic Energy Consumptions by Continents Source: Authors' own calculations.

According to Figure 2, the South and Eastern regions follow a similar primary energy consumption level especially in the years of 1998-2008 and have less energy consumption than the other regions. In the contrast, the North and Western regions have more primary energy consumption than the other regions and they follow a similar consumption level. All regions have breakdowns over the years along with the diplomacy between the countries, the financial crisis that affects industrialization, or the changes in politics. For instance, some countries may have non-renewable energy resources that give them a significant advantage over other countries. This allows them to use these energy sources, at a lower cost, in the production process, which in turn increases profits of companies involved in the production and enables increased investments in the economy. Therefore, the changes in politics, encouragements in using renewable energy resources, and financial crisis may affect the relations between the countries and may cause breakdowns over the years. 


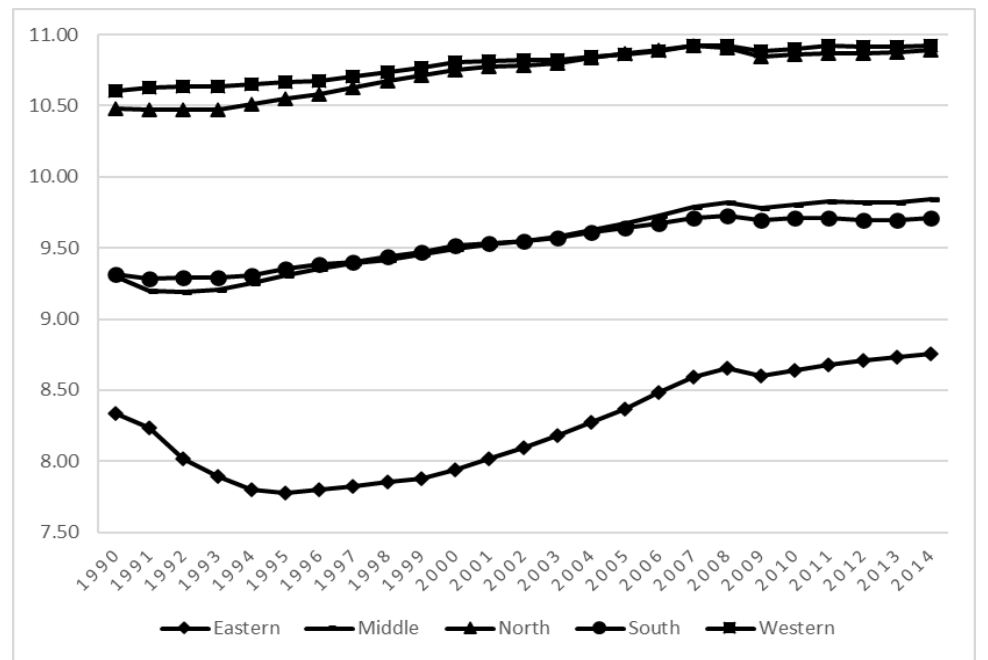

Figure 3. The Trend of Logarithmic GDP by Continents

Source: Authors' own calculations.

Figure 3 shows that the Eastern region has the less GDP per capita whereas the Western and North regions have the most GDP per capita. Just like in the primary energy consumption, all regions have breakdowns over the years.

\section{Methods and Empirical Results}

\subsection{Unit Root Analysis}

The first procedure that should be followed before analyzing the relationship between primary energy consumption and GDP per capita is the unit root analysis of the series. Some of the advantages of unit root analysis with panel data instead of time series are the power of the unit root test increases with the increase in the number of units and the asymptotic distributions of the test statistics are approximately normally distributed for the samples (Hadri, 2000). In order to determine the stationary levels of the series, we employ the Im, Pesaran, and Shin (IPS) test proposed by Im, Pesaran, and Shin (2003) and Fisher type tests ${ }^{8}$ proposed by Choi (2001) for heterogeneous panels. IPS and Fisher type tests are known as first-generation panel unit root tests. The first-generation panel unit root test may be divided into two categories as homogeneous and heterogeneous. Heterogenous panel unit root tests consider the panel specific autoregressive parameter while homogenous panel unit root tests such as Harris and Tzavalis (1999), Hadri (2000), Breitung (2000), Levin, Lin, and Chu (2002) assume the same autoregressive parameter for all units.

We also employ the Pesaran CADF and CIPS tests proposed by Pesaran (2003) in the case of cross-sectional dependence. IPS and Fisher type tests are known as first-generation conventional panel unit root tests whereas the Pesaran CADF and CIPS tests are known as second-generation. The main difference between the first- and second-generation panel unit root test is cross-sectional dependence across units. First-generation panel unit root tests such as IPS,

\footnotetext{
${ }^{8}$ Fisher type tests are known as Fisher ADF and Fisher PP tests. Fisher ADF test follows the logic in Augmented Dickey-Fuller unit root test whereas Fisher PP follows the Phillips-Perron unit root test. For more information, please see Choi (2001).
} 
Fisher type tests assume that there is no cross-sectional dependence between units. However, second-generation panel unit root tests do not have such an assumption and they are robust to cross-sectional dependence. In order to analyze the cross-sectional dependence of the panel data, the Pesaran CD test proposed by Pesaran (2004) employed. Table 2 reports the results of the Pesaran CD test.

Table 2. The Results of the Cross-sectional Dependence

\begin{tabular}{lcccc}
\hline & \multicolumn{2}{c}{ Logarithmic Energy Consumption } & \multicolumn{2}{c}{ Logarithmic GDP per capita } \\
\hline Region & CD Test Statistics & Probability & CD Test Statistics & Probability \\
\hline Eastern & $19.50^{* * *}$ & 0.000 & $26.40^{* * *}$ & 0.000 \\
Middle & 0.20 & 0.844 & $8.40^{* * *}$ & 0.000 \\
North & $3.46^{* * *}$ & 0.001 & $22.20^{* * *}$ & 0.000 \\
South & $12.88^{* * *}$ & 0.000 & $23.94^{* * *}$ & 0.000 \\
Western & $7.94^{* * *}$ & 0.000 & $22.15^{* * *}$ & 0.000 \\
\hline
\end{tabular}

Note: *** indicates the null hypothesis is rejected at the \%1 level.

According to the results, the null hypotheses are rejected at the $\% 1$ level of significance except for the logarithmic energy consumption in Middle Europe. Pesaran CD test provides evidence that logarithmic energy consumption and logarithmic GDP capita variables are crosssectionally dependent. Table 3 presents the results of the first- and second-generation panel unit root tests of the logarithmic energy consumption and logarithmic GDP per capita by region of the European continent. 
Table 3. The Results of The First- and Second-Generation Panel Unit Root Tests

\begin{tabular}{|c|c|c|c|c|c|c|c|c|c|c|}
\hline \multirow[b]{2}{*}{ Region } & \multicolumn{5}{|c|}{ Logarithmic Energy Consumption } & \multicolumn{5}{|c|}{ Logarithmic GDP per capita } \\
\hline & IPS & $\begin{array}{c}\text { Fisher } \\
\text { ADF }\end{array}$ & $\begin{array}{c}\text { Fisher } \\
\text { PP } \\
\end{array}$ & $\begin{array}{c}\text { Pesaran } \\
\text { CADF }\end{array}$ & $\begin{array}{l}\text { Pesaran } \\
\text { CIPS }\end{array}$ & IPS & $\begin{array}{l}\text { Fisher } \\
\text { ADF }\end{array}$ & $\begin{array}{l}\text { Fisher } \\
\text { PP }\end{array}$ & $\begin{array}{c}\text { Pesaran } \\
\text { CADF }\end{array}$ & $\begin{array}{l}\text { Pesaran } \\
\text { CIPS }\end{array}$ \\
\hline Eastern & $\begin{array}{c}-4.5485 * * * \\
(0.00) \\
\{0.44\}\end{array}$ & $\begin{array}{c}-2.3193 * * \\
(0.0102) \\
\{0\}\end{array}$ & $\begin{array}{c}-2.3193 * * \\
(0.0102) \\
\{0\}\end{array}$ & $\begin{array}{c}-2.842 * * \\
\{0\}\end{array}$ & $-2.132 *$ & $\begin{array}{c}-10.8303 * * * \\
(0.00) \\
\{0.89\}\end{array}$ & $\begin{array}{c}-8.1249 * * * \\
(0.00) \\
\{1\}\end{array}$ & $\begin{array}{c}-4.7369 * * * \\
(0.00) \\
\{1\}\end{array}$ & $\begin{array}{c}-417 * * * \\
\{1\}\end{array}$ & $-2.636 * * *$ \\
\hline Middle & $\begin{array}{c}0.7593 \\
(0.7762) \\
\{0\}\end{array}$ & $\begin{array}{c}0.8133 \\
(0.7920) \\
\{0\}\end{array}$ & $\begin{array}{c}0.8133(0.7920) \\
\{0\}\end{array}$ & $\begin{array}{c}-1.037 \\
\{0\}\end{array}$ & -1.645 & $\begin{array}{c}0.8634 \\
(0.8060) \\
\{1\}\end{array}$ & $\begin{array}{c}1.0861 \\
(0.8613) \\
\{1\}\end{array}$ & $\begin{array}{c}-1.7139 * * \\
(0.0433) \\
\{1\}\end{array}$ & $\begin{array}{c}-1.625 \\
\{1\}\end{array}$ & -0.981 \\
\hline North & $\begin{array}{c}1.3926 \\
(0.9181) \\
\{0.43\}\end{array}$ & $\begin{array}{c}0.2072 \\
(0.5821) \\
\{0\}\end{array}$ & $\begin{array}{c}0.2072(0.5821) \\
\{0\}\end{array}$ & $\begin{array}{c}-2.465 \\
\{0\}\end{array}$ & -1.476 & $\begin{array}{c}1.9528 \\
(0.9746) \\
\{0.86\}\end{array}$ & $\begin{array}{c}2.1768 \\
(0.985) \\
\{1\}\end{array}$ & $\begin{array}{c}3.7883 \\
(0.9999) \\
\{1\}\end{array}$ & $\begin{array}{c}-1.946 \\
\{1\}\end{array}$ & $-2.227 *$ \\
\hline South & $\begin{array}{c}2.3291 \\
(0.9901) \\
\{0.11\}\end{array}$ & $\begin{array}{c}-0.7984 \\
(0.2123) \\
\{0\}\end{array}$ & $\begin{array}{c}-0.7984(0.2123) \\
\{0\}\end{array}$ & $\begin{array}{c}-2.866^{* *} \\
\{0\}\end{array}$ & -1.388 & $\begin{array}{c}1.8035 \\
(0.9643) \\
\{0.44\}\end{array}$ & $\begin{array}{c}1.0306 \\
(0.8484) \\
\{0\}\end{array}$ & $\begin{array}{c}1.0306 \\
(0.8486) \\
\{0\}\end{array}$ & $\begin{array}{c}-2.763 * \\
\{0\}\end{array}$ & -0.728 \\
\hline Western & $\begin{array}{c}2.3418 \\
(0.9904) \\
\{0.57\}\end{array}$ & $\begin{array}{c}4.1449 \\
(1.0000) \\
\{1\}\end{array}$ & $\begin{array}{c}2.3513 \\
(0.9906) \\
\{1\}\end{array}$ & $\begin{array}{c}-2.250 \\
\{1\}\end{array}$ & $-2.141 *$ & $\begin{array}{c}1.5818 \\
(0.9432) \\
\{0.43\}\end{array}$ & $\begin{array}{c}2.8111 \\
(0.9975) \\
\{0\}\end{array}$ & $\begin{array}{c}1.7579 \\
(0.9606) \\
\{0\}\end{array}$ & $\begin{array}{c}-1.974 \\
\{0\}\end{array}$ & -1.580 \\
\hline
\end{tabular}

Notes: (i) *, **, and *** indicate the null hypothesis is rejected at the $\% 10, \% 5$ and $\% 1$ levels, respectively. (ii)The numbers in the brackets indicate the probability of the test statistics and the numbers in the curly brackets indicate the lag length. (iii) Lags criterion decision of IPS is based on Akaike Information Criterion. (iv) Fisher ADF indicates the inverse normal test statistics. (v) Lags criterion decision of Pesaran CIPS with the maximum lag 1 is based on general to particular based on F joint test. (vi) The critical values of Pesaran CIPS are $-2.12,-2.25$, and -2.51 , at the levels of $10 \%$, 5\%, and $1 \%$, respectively. 
According to Table 3, most of the unit root tests indicate that the null hypothesis that refers to the unit root cannot be rejected at any reasonable levels for the regions except for Eastern Europe. However, relatively recent panel unit root tests such as IPS, Fisher type, CADF, and CIPS do not allow for the possibility of structural breaks in the series. As Perron (1989) emphasizes the importance of considering the structural break over the time series, if the time series contains a structural break, we may reject the null hypothesis even though the series is stationary if we do not consider the break in the test procedure. Perron (1989) is the first to analyze unit root for the time series with a structural break that determined exogenously. Later, Zivot and Andrews (1992) proposed the unit root test for the time series with an endogenously determined structural break. Following the ideas of unit root tests with structural break, Im et al. (2005; 2010) (ILT) proposed panel unit root tests with structural breaks in level and trend, determined endogenously. ILT test procedure follows the data-generating process in Model 1 for the level shift model.

$$
y_{i t}=\delta^{\prime} Z_{i t}+e_{i t}, e_{i t}=\beta e_{i, t-1}+\varepsilon_{i t}
$$

$Z_{i t}$ denotes the deterministic variables. If the series contains level-shift structural break $Z_{i t}$ contains the deterministic variables in Equation 2 and generates the crash model whereas the series contains trend-shift structural break it contains the deterministic variables in Equation 3 and generates the trend in break model.

$$
\begin{gathered}
Z_{i t}=\left[1, t, D_{i t}\right]^{\prime} \\
Z_{i t}=\left[1, t, D_{i t}, D T_{i t}^{*}\right]^{\prime}
\end{gathered}
$$

1 and $t$ indicate the constant and trend while $D_{i t}$ and $D T_{i t}^{*}$ indicate the break dummies. ILT test determines the optimal number of structural changes for each panel. ILT test examines the significance of dummy coefficients based on the t-test to determine the structural breaks (Im et al., 2005). In this way, the test determines the panel LM test statistics as well as the break locations, the optimal lag, and the Lagrangian Multiplier (LM) test statistics for each panel. The description of the dummies are in Equations 4 and 5

$$
\begin{aligned}
D_{i t} & =\left\{\begin{array}{c}
1 t>T B \\
0 \text { otherwise }
\end{array}\right. \\
D T_{i t}^{*} & =\left\{\begin{array}{c}
t-T B t>T B \\
0 \text { otherwise }
\end{array}\right.
\end{aligned}
$$

where $T B$ indicates the break location. If the series contains two structural breaks, the dummies in Equations 4 and 5 are defined for each structural break for the panels. Basically, ILT follows the same logic in Lee and Strazicich $(2003 ; 2004)$ time series unit root processes and adopts LM principle while analyzing the unit root with structural breaks. According to Im, Lee, and Tieslau (2005), ILT test is not only robust to the presence of structural shifts but is more powerful than the IPS test. Furthermore, ILT test analyses unit root and structural shifts of the units separately for each unit in the panel data.

Since the first- and second-generation panel unit root tests do not consider the structural breaks over trends of the series, we adopt the unit root test procedure proposed by $\mathrm{Im}$, Lee, and Tieslau $(2005 ; 2010)$ that considers structural breaks in level and trend. Table 4 and 5 present the ILT panel unit root test results of logarithmic energy consumption and logarithmic GDP per capita by regions and countries both level shift and trend shift models with one and two breaks. 
Ekonomi, Politika \& Finans Araştırmaları Dergisi, 2021, 6(3): 587-607

Journal of Research in Economics, Politics \& Finance, 2021, 6(3): 587-607

Table 4. The ILT Tests Results of Logarithmic Energy Consumption

\begin{tabular}{|c|c|c|c|c|c|c|c|c|c|c|c|c|}
\hline \multirow[b]{3}{*}{ Region } & \multicolumn{6}{|c|}{ One Break } & \multicolumn{6}{|c|}{ Two Breaks } \\
\hline & \multicolumn{3}{|c|}{ Level Shift Model } & \multicolumn{3}{|c|}{ Trend Shift Model } & \multicolumn{3}{|c|}{ Level Shift Model } & \multicolumn{3}{|c|}{ Trend Shift Model } \\
\hline & $\begin{array}{c}\text { LM } \\
\text { Statistics } \\
\end{array}$ & $\begin{array}{c}\text { Optimal } \\
\text { Lag }\end{array}$ & $\begin{array}{c}\text { Break } \\
\text { Location }\end{array}$ & $\begin{array}{c}\mathbf{L M} \\
\text { Statistics }\end{array}$ & $\begin{array}{c}\text { Optimal } \\
\text { Lag }\end{array}$ & $\begin{array}{c}\text { Break } \\
\text { Location }\end{array}$ & $\begin{array}{c}\text { LM } \\
\text { Statistics }\end{array}$ & $\begin{array}{c}\text { Optimal } \\
\text { Lag }\end{array}$ & $\begin{array}{c}\text { Break } \\
\text { Location }\end{array}$ & $\begin{array}{c}\text { LM } \\
\text { Statistics }\end{array}$ & $\begin{array}{c}\text { Optimal } \\
\text { Lag }\end{array}$ & $\begin{array}{c}\text { Break } \\
\text { Location }\end{array}$ \\
\hline \multicolumn{13}{|l|}{ Eastern } \\
\hline Armenia & -1.193 & 3 & 1996 & $-7.989 * * *$ & 1 & 1995 & -2.633 & 1 & 1997, 2004 & $-9.077 * * *$ & 1 & 1996,2003 \\
\hline Azerbaijan & -2.784 & 3 & 2007 & $-4.329 * * *$ & 3 & 2007 & -2.540 & 1 & 1998, 2007 & $-4.833 * * *$ & 1 & 1999,2007 \\
\hline Belarus & $-3.624 *$ & 3 & 1995 & $-4.779 * * *$ & 3 & 1999 & -2.129 & 1 & 1996,2012 & $-5.992 * * *$ & 1 & 1997,2003 \\
\hline Bulgaria & $-4.105 * *$ & 1 & 1997 & $-7.423 * * *$ & 1 & 1998 & -2.760 & 0 & 2000,2004 & $-4.665 * *$ & 3 & 2003,2012 \\
\hline Georgia & -1.692 & 3 & 2008 & -3.323 & 3 & 2003 & -1.615 & 3 & 1998,2000 & $-9.959 * * *$ & 3 & 1998,2006 \\
\hline Kazakhstan & $-3.542 *$ & 2 & 1999 & $-3.478 *$ & 2 & 2004 & -2.905 & 3 & 2004, 2008 & $-4.716 * *$ & 2 & 1997, 2004 \\
\hline Romania & $-4.377 * * *$ & 1 & 2009 & $-7.911 * * *$ & 1 & 1999 & -2.011 & 1 & 2002, 2009 & $-5.669 * * *$ & 3 & 1998,2008 \\
\hline $\begin{array}{l}\text { Russian } \\
\text { Federation }\end{array}$ & -1.513 & 1 & 1995 & $-3.703^{*}$ & 2 & 1999 & -2.075 & 2 & 1995, 2010 & $-8.400 * * *$ & 3 & 1998,2008 \\
\hline Ukraine & -2.252 & 0 & 2005 & $-3.723 * *$ & 3 & 1999 & -2.468 & 3 & 2007,2010 & $-5.146 * * *$ & 2 & 1998,2008 \\
\hline $\begin{array}{l}\text { Panel LM test } \\
\text { statistics }\end{array}$ & $-3.993 * *$ & & & $-15.151 * * *$ & & & -1.912 & & & $-21.229 * * *$ & & \\
\hline \multicolumn{13}{|l|}{ Middle } \\
\hline $\begin{array}{l}\text { Czech } \\
\text { Republic }\end{array}$ & -2.759 & 3 & 1998 & -3.433 & 3 & 1998 & -2.510 & 3 & 1998, 2009 & $-4.271 *$ & 3 & 1996, 2004 \\
\hline Poland & $-3.575^{*}$ & 3 & 1995 & -3.079 & 3 & 2009 & -2.194 & 0 & 2005,2007 & $-5.558 * * *$ & 3 & 1997,2008 \\
\hline Slovenia & -2.027 & 3 & 1995 & -3.298 & 3 & 2003 & $-4.536 * *$ & 2 & 2000,2008 & $-5.904 * * *$ & 2 & 2000,2008 \\
\hline $\begin{array}{l}\text { Panel LM test } \\
\text { statistics }\end{array}$ & -2.384 & & & $-3.658^{*}$ & & & -3.155 & & & $-8.969 * * *$ & & \\
\hline \multicolumn{13}{|l|}{ North } \\
\hline Denmark & -2.904 & 3 & 1995 & $-3.929 * *$ & 0 & 1998 & -3.585 & 0 & 2008,2010 & $-6.916 * * *$ & 0 & 1997,2006 \\
\hline Finland & $-3.536^{*}$ & 0 & 2007 & $-4.998 * * *$ & 1 & 2003 & -2.828 & 0 & 2008, 2011 & $-6.245 * * *$ & 1 & 2003, 2006 \\
\hline Iceland & -1.695 & 1 & 2010 & $-3.721 * *$ & 0 & 2006 & -2.295 & 1 & 1996, 2010 & $-4.541 * *$ & 3 & 1997,2005 \\
\hline Ireland & $-4.008 * *$ & 3 & 2004 & $-3.969 * *$ & 3 & 2004 & $-4.740 * *$ & 3 & 2002, 2004 & $-4.350 * *$ & 3 & 2006,2010 \\
\hline Norway & $-4.601 * * *$ & 0 & 2007 & $-5.021 * * *$ & 3 & 2006 & $-4.260^{*}$ & 0 & 2007, 2010 & $-7.206 * * *$ & 2 & 2003, 2009 \\
\hline Sweden & $-3.597 *$ & 3 & 2002 & $-5.704 * * *$ & 3 & 2006 & $-6.540 * * *$ & 3 & 1997, 2008 & $-7.993 * * *$ & 3 & 2003,2008 \\
\hline $\begin{array}{l}\text { United } \\
\text { Kingdom }\end{array}$ & -1.981 & 1 & 2012 & $-4.628 * * *$ & 1 & 2007 & -2.218 & 0 & 1995, 2008 & $-7.377 * * *$ & 3 & 1995,2003 \\
\hline $\begin{array}{l}\text { Panel LM test } \\
\text { statistics }\end{array}$ & $-5.136 * * *$ & & & $-10.800 * * *$ & & & $-7.598 * * *$ & & & $-18.254 * * *$ & & \\
\hline
\end{tabular}


M. Y1lgör, S. Korkmaz \& F. Kömüryakan, “The Relationship between Non-Renewable Energy Consumption and Economic Growth: A Regional Analysis of European Continent"

Table 4 (Continued). The ILT Tests Results of Logarithmic Energy Consumption

\begin{tabular}{|c|c|c|c|c|c|c|c|c|c|c|c|c|}
\hline \multirow[b]{3}{*}{ Region } & \multicolumn{6}{|c|}{ One Break } & \multicolumn{6}{|c|}{ Two Breaks } \\
\hline & \multicolumn{3}{|c|}{ Level Shift Model } & \multicolumn{3}{|c|}{ Trend Shift Model } & \multicolumn{3}{|c|}{ Level Shift Model } & \multicolumn{3}{|c|}{ Trend Shift Model } \\
\hline & $\begin{array}{c}\text { LM } \\
\text { Statistics } \\
\end{array}$ & $\begin{array}{c}\text { Optimal } \\
\text { Lag }\end{array}$ & $\begin{array}{c}\text { Break } \\
\text { Location }\end{array}$ & $\begin{array}{c}\text { LM } \\
\text { Statistics } \\
\end{array}$ & $\begin{array}{c}\text { Optimal } \\
\text { Lag }\end{array}$ & $\begin{array}{c}\text { Break } \\
\text { Location }\end{array}$ & $\begin{array}{c}\text { LM } \\
\text { Statistics } \\
\end{array}$ & $\begin{array}{c}\text { Optimal } \\
\text { Lag }\end{array}$ & $\begin{array}{c}\text { Break } \\
\text { Location }\end{array}$ & $\begin{array}{c}\mathbf{L M} \\
\text { Statistics } \\
\end{array}$ & $\begin{array}{c}\text { Optimal } \\
\text { Lag }\end{array}$ & $\begin{array}{c}\text { Break } \\
\text { Location }\end{array}$ \\
\hline \multicolumn{13}{|l|}{ South } \\
\hline Albania & -1.657 & 0 & 1997 & $-3.488 *$ & 1 & 1995 & -3.317 & 3 & 1996,2012 & $-5.516 * * *$ & 3 & 1997,2005 \\
\hline Cyprus & -2.354 & 0 & 2010 & $-3.606^{*}$ & 3 & 1998 & -3.217 & 2 & 1995,2012 & $-4.857 * * *$ & 0 & 1996,2010 \\
\hline Greece & -2.980 & 0 & 2009 & $-4.949 * * *$ & 0 & 2008 & $-4.072 * *$ & 3 & 1998,2011 & $-5.178 * * *$ & 3 & 2003,2011 \\
\hline Italy & -3.422 & 0 & 2008 & $-5.217 * * *$ & 0 & 1999 & -2.033 & 3 & 1997,2012 & $-4.606 * *$ & 2 & 2003,2008 \\
\hline Malta & $-5.446 * * *$ & 2 & 1997 & $-6.344 * * *$ & 2 & 2000 & $-6.680 * * *$ & 2 & 2002,2004 & $-8.879 * * *$ & 2 & 2000,2005 \\
\hline $\begin{array}{l}\text { North } \\
\text { Macedonia }\end{array}$ & -3.367 & 3 & 1995 & $-3.582 *$ & 0 & 2000 & $-4.380^{* * *}$ & 0 & 1998,2012 & $-6.055^{* * *}$ & 1 & 1997, 2004 \\
\hline Portugal & -1.651 & 0 & 2005 & $-6.155^{* * *}$ & 1 & 2001 & -2.786 & 3 & 1995,2005 & $-6.062 * * *$ & 0 & 1997, 2006 \\
\hline Spain & -2.602 & 3 & 2012 & -3.216 & 3 & 1997 & $-3.826 * *$ & 3 & 2008,2012 & $-4.713 * *$ & 3 & 2002,2012 \\
\hline Turkey & -1.825 & 2 & 2007 & $-3.573 *$ & 1 & 2000 & -3.275 & 0 & 1996,2005 & $-4.641 * *$ & 1 & 1996, 2004 \\
\hline $\begin{array}{l}\text { Panel LM test } \\
\text { statistics }\end{array}$ & $-4.130 * *$ & & & $-11.787 * * *$ & & & $-8.500 * * *$ & & & $-17.237 * * *$ & & \\
\hline \multicolumn{13}{|l|}{ Western } \\
\hline Austria & $-4.456 * * *$ & 2 & 2008 & $-4.584 * * *$ & 3 & 2003 & -2.521 & 0 & 1995,2000 & $-10.848 * * *$ & 3 & 2003,2008 \\
\hline Belgium & -2.165 & 3 & 2011 & $-3.698 *$ & 3 & 2004 & -3.115 & 3 & 2003, 2011 & $-8.312 * * *$ & 3 & 1997,2008 \\
\hline France & -2.054 & 0 & 2005 & $-4.567 * * *$ & 0 & 2003 & -2.633 & 0 & 2008,2010 & $-7.263 * * *$ & 3 & 2003,2011 \\
\hline Germany & -2.035 & 0 & 2010 & -3.275 & 1 & 2006 & $-3.627 *$ & 0 & 1995,2000 & $-5.497 * * *$ & 0 & 1995, 1999 \\
\hline Luxembourg & -2.893 & 3 & 2003 & $-5.675^{* *}$ & 3 & 2003 & -2.746 & 3 & 2007, 2009 & $-5.526 * * *$ & 3 & 2003, 2009 \\
\hline Netherlands & -2.881 & 0 & 1995 & $-4.166 * *$ & 3 & 2000 & -3.310 & 0 & 1995,2010 & $-4.887 * * *$ & 3 & 2001,2008 \\
\hline Switzerland & $-4.298 * * *$ & 0 & 2007 & $-4.331 * * *$ & 0 & 2002 & -3.282 & 0 & 2000,2010 & $-5.857 * * *$ & 0 & 1995,2010 \\
\hline $\begin{array}{l}\text { Panel LM test } \\
\text { statistics }\end{array}$ & $-4.286 * * *$ & & & $-9.845 * * *$ & & & $-4.507 * *$ & & & $-20.311 * * *$ & & \\
\hline
\end{tabular}

Notes: (i) ILT test procedure determines the number of augmentations using the general-to-specific procedure of Ng and Perron (1995). (ii) ILT test procedure determines the break locations through a grid search over the time interval $[0.1 \mathrm{~T}, 0.9 \mathrm{~T}]$. (ii) *,**, and *** indicate the null hypothesis is rejected at the $\% 10, \% 5$ and $\% 1$ levels, respectively. (iii) For the critical values, please see Im et al. (2010). 
Ekonomi, Politika \& Finans Araştırmaları Dergisi, 2021, 6(3): 587-607

Journal of Research in Economics, Politics \& Finance, 2021, 6(3): 587-607

Table 5. The ILT Tests Results of Logarithmic GDP Per Capita

\begin{tabular}{|c|c|c|c|c|c|c|c|c|c|c|c|c|}
\hline \multirow[b]{3}{*}{ Continent } & \multicolumn{6}{|c|}{ One Break } & \multicolumn{6}{|c|}{ Two Breaks } \\
\hline & \multicolumn{3}{|c|}{ Level Shift Model } & \multicolumn{3}{|c|}{ Trend Shift Model } & \multicolumn{3}{|c|}{ Level Shift Model } & \multicolumn{3}{|c|}{ Trend Shift Model } \\
\hline & $\begin{array}{c}\text { LM } \\
\text { Statistics }\end{array}$ & $\begin{array}{c}\text { Optimal } \\
\text { Lag }\end{array}$ & $\begin{array}{c}\text { Break } \\
\text { Location }\end{array}$ & $\begin{array}{c}\mathbf{L M} \\
\text { Statistics } \\
\end{array}$ & $\begin{array}{c}\text { Optimal } \\
\text { Lag }\end{array}$ & $\begin{array}{c}\text { Break } \\
\text { Location }\end{array}$ & $\begin{array}{c}\mathbf{L M} \\
\text { Statistics } \\
\end{array}$ & $\begin{array}{c}\text { Optimal } \\
\text { Lag }\end{array}$ & $\begin{array}{c}\text { Break } \\
\text { Location }\end{array}$ & $\begin{array}{c}\text { LM } \\
\text { Statistics }\end{array}$ & $\begin{array}{c}\text { Optimal } \\
\text { Lag }\end{array}$ & $\begin{array}{c}\text { Break } \\
\text { Location }\end{array}$ \\
\hline \multicolumn{13}{|l|}{ Eastern } \\
\hline Armenia & $-7.588 * * *$ & 2 & 2008 & $-6.616 * * *$ & 2 & 2008 & -1.815 & 1 & 1995,2009 & $-6.554 * * *$ & 1 & 1995,2005 \\
\hline Azerbaijan & -2.905 & 1 & 2011 & $-4.988 * * *$ & 3 & 2005 & -3.251 & 1 & 1998, 2011 & $-7.370 * * *$ & 1 & 1998, 2006 \\
\hline Belarus & -1.648 & 2 & 2000 & $-6.443 * * *$ & 1 & 2002 & -2.879 & 1 & 1997,2009 & $-6.053 * * *$ & 1 & 1998,2008 \\
\hline Bulgaria & -2.354 & 2 & 1998 & $-5.212 * * *$ & 2 & 1998 & -2.339 & 1 & 1996,1998 & $-5.348 * * *$ & 2 & 1997,2005 \\
\hline Georgia & -2.048 & 3 & 2009 & $-6.534 * * *$ & 1 & 1998 & -2.612 & 1 & 1995,1997 & $-9.413 * * *$ & 1 & 1995,2001 \\
\hline Kazakhstan & -2.743 & 1 & 2012 & $-5.099 * * *$ & 1 & 2007 & $-4.500 * *$ & 3 & 2009,2012 & $-4.391 * * *$ & 1 & 1995,2003 \\
\hline Romania & -2.755 & 1 & 1997 & $-5.848 * * *$ & 1 & 1998 & -1.767 & 1 & 2001,2010 & $-5.955 * * *$ & 3 & 1998,2007 \\
\hline $\begin{array}{l}\text { Russian } \\
\text { Federation }\end{array}$ & -2.575 & 2 & 1999 & $-4.506^{* * *}$ & 2 & 2000 & -2.898 & 2 & 1997,2008 & $-7.559 * * *$ & 3 & 1997,2008 \\
\hline Ukraine & $-5.381 * * *$ & 3 & 2003 & $-6.065^{* * *}$ & 3 & 2002 & -3.267 & 3 & 1996, 2011 & $-4.536^{* *}$ & 1 & 1996,2005 \\
\hline $\begin{array}{l}\text { Panel LM test } \\
\text { statistics }\end{array}$ & $-6.618 * * *$ & & & $-17.614 * * *$ & & & $-4.026^{*}$ & & & $-20.480 * * *$ & & \\
\hline \multicolumn{13}{|l|}{ Middle } \\
\hline $\begin{array}{l}\text { Czech } \\
\text { Republic }\end{array}$ & -1.844 & 1 & 2001 & $-3.508^{*}$ & 1 & 2002 & -2.607 & 1 & 1996, 2009 & $-5.310 * * *$ & 2 & 1997, 2008 \\
\hline Poland & -2.423 & 1 & 2009 & -3.063 & 1 & 2002 & $-4.330 *$ & 3 & 1997,2005 & $-4.517 * *$ & 3 & 2005,2009 \\
\hline Slovenia & -2.602 & 3 & 1995 & -2.661 & 3 & 1996 & -2.994 & 1 & 1995, 2009 & $-6.122 * * *$ & 1 & 1995,2008 \\
\hline $\begin{array}{l}\text { Panel LM test } \\
\text { statistics }\end{array}$ & -0.915 & & & -3.021 & & & -3.643 & & & $-9.139 * * *$ & & \\
\hline \multicolumn{13}{|l|}{ North } \\
\hline Denmark & -2.743 & 2 & 2006 & -3.066 & 3 & 2000 & -2.464 & 3 & 1995,2011 & $-5.466 * * *$ & 2 & 2000,2007 \\
\hline Finland & -2.254 & 3 & 2009 & -2.201 & 1 & 1996 & -3.870 & 3 & 1997,2008 & $-4.336 * *$ & 1 & 1995,2005 \\
\hline Iceland & -1.715 & 0 & 2006 & -3.324 & 1 & 2005 & -2.748 & 3 & 1996, 1998 & $-6.809 * * *$ & 3 & 1997, 2007 \\
\hline Ireland & -3.194 & 3 & 2006 & -3.342 & 3 & 1997 & -3.609 & 3 & 1997, 2007 & $-4.973 * * *$ & 3 & 1997, 2006 \\
\hline Norway & -2.263 & 3 & 1995 & -2.688 & 1 & 1998 & -2.701 & 3 & 2005,2008 & $-6.534 * * *$ & 3 & 2000,2008 \\
\hline Sweden & -1.486 & 1 & 2012 & $-3.691 *$ & 1 & 2000 & -3.100 & 3 & 2005,2009 & $-5.875 * * *$ & 1 & 1996,2008 \\
\hline $\begin{array}{l}\text { United } \\
\text { Kingdom }\end{array}$ & -3.396 & 3 & 2003 & $-3.772 * *$ & 3 & 2003 & -2.969 & 3 & 2005,2008 & $-5.792 * * *$ & 3 & 1996, 2007 \\
\hline $\begin{array}{l}\text { Panel LM test } \\
\text { statistics }\end{array}$ & -2.144 & & & $-4.957 * * *$ & & & $-4.765 * *$ & & & $-15.362 * * *$ & & \\
\hline
\end{tabular}


Table 5 (Continued). The ILT Tests Results of Logarithmic GDP Per Capita

\begin{tabular}{|c|c|c|c|c|c|c|c|c|c|c|c|c|}
\hline \multirow[b]{3}{*}{ Continent } & \multicolumn{6}{|c|}{ One Break } & \multicolumn{6}{|c|}{ Two Breaks } \\
\hline & \multicolumn{3}{|c|}{ Level Shift Model } & \multicolumn{3}{|c|}{ Trend Shift Model } & \multicolumn{3}{|c|}{ Level Shift Model } & \multicolumn{3}{|c|}{ Trend Shift Model } \\
\hline & $\begin{array}{c}\text { LM } \\
\text { Statistics } \\
\end{array}$ & $\begin{array}{c}\text { Optimal } \\
\text { Lag }\end{array}$ & $\begin{array}{c}\text { Break } \\
\text { Location }\end{array}$ & $\begin{array}{c}\text { LM } \\
\text { Statistics } \\
\end{array}$ & $\begin{array}{c}\text { Optimal } \\
\text { Lag }\end{array}$ & $\begin{array}{c}\text { Break } \\
\text { Location }\end{array}$ & $\begin{array}{c}\text { LM } \\
\text { Statistics } \\
\end{array}$ & $\begin{array}{c}\text { Optimal } \\
\text { Lag }\end{array}$ & $\begin{array}{c}\text { Break } \\
\text { Location }\end{array}$ & $\begin{array}{c}\text { LM } \\
\text { Statistics } \\
\end{array}$ & $\begin{array}{c}\text { Optimal } \\
\text { Lag }\end{array}$ & $\begin{array}{c}\text { Break } \\
\text { Location }\end{array}$ \\
\hline \multicolumn{13}{|l|}{ South } \\
\hline Albania & $-3.812 * *$ & 1 & 1996 & $-8.544 * * *$ & 3 & 1997 & $-5.644 * * *$ & 1 & 1996,2000 & $-9.704 * * *$ & 3 & 1997,2006 \\
\hline Cyprus & -1.093 & 3 & 2008 & $-4.676 * * *$ & 3 & 2002 & -3.271 & 3 & 1996,2008 & $-5.238 * * *$ & 3 & 1997,2005 \\
\hline Greece & -1.555 & 1 & 2005 & $-4.377 * * *$ & 3 & 2005 & $-4.251 *$ & 3 & 2010,2012 & $-16.174 * * *$ & 3 & 1995,2005 \\
\hline Italy & -0.633 & 1 & 2011 & -3.155 & 3 & 1997 & -2.534 & 3 & 1997,2009 & $-5.645^{* * *}$ & 1 & 1999,2005 \\
\hline Malta & $-4.252 * *$ & 3 & 2010 & -3.017 & 3 & 2012 & -2.588 & 3 & 2000,2006 & $-5.552 * * *$ & 3 & 1997, 2009 \\
\hline $\begin{array}{l}\text { North } \\
\text { Macedonia }\end{array}$ & -1.662 & 1 & 2004 & $-4.225^{*}$ & 3 & 2001 & -1.536 & 1 & 2000,2009 & $-5.275^{* * *}$ & 3 & 1997,2005 \\
\hline Portugal & -1.391 & 0 & 2002 & -3.708 & 1 & 1999 & -3.066 & 3 & 2003,2009 & $-6.173 * * *$ & 1 & 1997, 2009 \\
\hline Spain & -1.430 & 0 & 2006 & -3.490 & 0 & 2004 & -3.426 & 3 & 1999,2005 & $-4.735 * *$ & 2 & 2002,2011 \\
\hline Turkey & -1.985 & 1 & 2000 & $-4.229 * *$ & 2 & 1999 & $-4.919 * * *$ & 3 & 1998,2004 & $-6.708 * * *$ & 3 & 1996,1999 \\
\hline $\begin{array}{l}\text { Panel LM test } \\
\text { statistics }\end{array}$ & -0.095 & & & $-11.436 * * *$ & & & $-7.185 * * *$ & & & $-24.594 * * *$ & & \\
\hline \multicolumn{13}{|l|}{ Western } \\
\hline Austria & $-3.663 *$ & 0 & 1995 & -3.357 & 0 & 2000 & -2.063 & 1 & 2001,2009 & $-5.013 * * *$ & 1 & 1997,2004 \\
\hline Belgium & $-4.114 * *$ & 3 & 2002 & $-4.283 * * *$ & 3 & 2002 & -2.454 & 3 & 1999, 2012 & $-4.577 * *$ & 2 & 1999, 2006 \\
\hline France & $-3.960 * *$ & 0 & 2006 & $-3.800 * *$ & 0 & 2005 & -2.630 & 3 & 2005,2010 & $-5.636 * * *$ & 2 & 1998, 2008 \\
\hline Germany & -1.719 & 3 & 2010 & -2.698 & 3 & 2002 & $-6.302 * * *$ & 1 & 2001,2007 & $-5.571 * * *$ & 1 & 2000,2011 \\
\hline Luxembourg & -1.842 & 0 & 2007 & $-5.929 * * *$ & 3 & 2007 & -2.032 & 0 & 1998,2008 & $-5.240 * * *$ & 3 & 2003, 2007 \\
\hline Netherlands & -3.136 & 2 & 2009 & $-4.246 * *$ & 1 & 1995 & -2.675 & 3 & 2003,2005 & $-6.100 * * *$ & 1 & 1997, 2009 \\
\hline Switzerland & -1.048 & 0 & 2004 & -3.105 & 0 & 2001 & -2.821 & 1 & 1998,2009 & $-5.288 * * *$ & 2 & 1996,2010 \\
\hline $\begin{array}{l}\text { Panel LM test } \\
\text { statistics }\end{array}$ & $-3.512 *$ & & & $-8.161 * * *$ & & & $-4.329 * *$ & & & $-14.125 * * *$ & & \\
\hline
\end{tabular}

Notes: (i) ILT test procedure determines the number of augmentations using the general-to-specific procedure of Ng and Perron (1995). (ii) ILT test procedure determines the break locations through a grid search over the time interval [0.1T, 0.9T]. (ii) *, **, and *** indicate the null hypothesis is rejected at the $\% 10, \% 5$ and $\% 1$ levels, respectively. (iii) For the critical values, please see Im et al. (2010). 
ILT test provides results about the structural breaks not only region-wise but also unitwise in the panel data. Tables 4 and 5 indicate that there are two significant breakdowns for the logarithmic energy consumption and logarithmic GDP per capita series of the countries and the breakdowns occur in trends. According to Table 4, the structural breaks of logarithmic energy consumption mostly occur in the years 1998 and 2006 for Eastern Europe, in the years 1997 and 2006 for Middle Europe, in the years 2000 and 2006 for North Europe, and in the years 1999 and 2007 for the South and Western Europe. The structural breaks of logarithmic GDP per capita mostly occur in the years 1996 and 2005 for Eastern Europe, in the years 1999 and 2008 for Middle Europe, in the years 1997 and 2006 for North and South Europe, and in the years 1998 and 2007 for Western Europe. The results show that logarithmic energy consumption and logarithmic GDP per capita panel series are stationary with two structural breaks in the trend shift model.

\subsection{Homogeneity Analysis}

Since the logarithmic energy consumption and logarithmic GDP per capita series are stationary with two structural breaks in the trend shift model, the series are estimated with the structural break dummies proposed in Im et al. $(2005 ; 2010)$. The second procedure to examine the relationship between logarithmic energy consumption and logarithmic GDP per capita is the homogeneity of the stationary series. In order to analyze the homogeneity of the panel data, the homogeneity test proposed by Swamy (1970) is employed. Table 6 presents the region-wise results of the Swamy homogeneity test.

Table 6. The Results of Homogeneity Analyses

\begin{tabular}{lcc}
\hline \multirow{2}{*}{ Region } & $\begin{array}{c}\text { Logarithmic Energy } \\
\text { Consumption }\end{array}$ & $\begin{array}{c}\text { Logarithmic GDP per } \\
\text { capita }\end{array}$ \\
\hline \multirow{2}{*}{ Eastern } & $1838.91^{* * *}$ & $967.86^{* * *}$ \\
& $(0.000)$ & $(0.000)$ \\
Middle & $161.72^{* * *}$ & $24.19^{* * *}$ \\
& $(0.000)$ & $(0.000)$ \\
North & $1540.03^{* * *}$ & $406.44 * * *$ \\
& $(0.000)$ & $(0.000)$ \\
South & $516.67 * * *$ & $3682.68^{* * *}$ \\
& $(0.000)$ & $(0.000)$ \\
Western & $2037.68^{* * *}$ & $4464.43^{* * *}$ \\
& $(0.000)$ & $(0.000)$ \\
\hline
\end{tabular}

Notes: (i) The number in the brackets denote the probability of the test statistics. (ii) $* * *$ indicates the null hypothesis is rejected at the $\% 1$ level.

The null hypothesis of the homogeneity test indicates the homogeneity in the panel data. According to Table 6, the null hypothesis is rejected at a $1 \%$ level. Therefore, the region-wise panel data are heterogeneous. 


\subsection{Causality Analysis}

Third and last procedure of this study to examine the relationship between logarithmic energy consumption and logarithmic GDP per capita is panel causality analysis. Unlike time series analysis, heterogeneity in the panel data determines the further analysis process for the variables. Dumitrescu and Hurlin (2012) proposed a panel Granger causality process in order to examine the causality in heterogeneous panel. This test procedure considers the heterogeneity of the causal relationships and the heterogeneity of the regression model. Heterogeneous panel causality analysis adopts the following linear model for the two stationary variables denoted by $Y$ and $X$ for $N$ individuals on $T$ periods

$$
Y_{i, t}=\alpha_{i}+\sum_{k=1}^{K} \gamma_{i}^{k} Y_{i, t-k}+\sum_{k=1}^{K} \delta_{i}^{k} X_{i, t-k}+\varepsilon_{i t}
$$

with $K \in \mathbb{N}^{*}$ and $\delta_{i}=\left(\delta_{i}^{(1)}, \ldots, \delta_{i}^{(K)}\right)^{\prime}$. The test procedure assumes that augmentations are identical for all cross-sections and allows the autoregressive parameters and slopes to differ across groups. The null and alternative hypotheses of the heterogenous panel causality analysis are defined as in Equation 7.

$$
\begin{gathered}
H_{0}: \delta_{i}=0 \quad \forall i=1, \ldots, N \\
H_{1}:\left\{\begin{array}{c}
\delta_{i}=0 \quad \forall i=1, \ldots, N_{1} \\
\delta_{i} \neq 0 \quad \forall i=N_{1}+1, N_{1}+2, \ldots, N
\end{array}\right.
\end{gathered}
$$

The null hypothesis states the variable $X$ does not Granger cause the variable $Y$ for all the panels. The alternative hypothesis states two situations: $X$ Granger causes $Y$ for all the individuals of the panels and the regression model and the causality relations differs from one individual from the sample to another. This test procedure based on the individual Wald statistics denoted by $W$ across the units and contains two more revised test statistics denoted by $\bar{Z}$ and $\tilde{Z}$. The test statistic $\bar{Z}$ indicates the case of first $T \rightarrow \infty$ and then $N \rightarrow \infty$ whereas $\tilde{Z}$ indicates $\mathrm{T}$ is fixed and $N \rightarrow \infty$. W and $\bar{Z}$ test statistics defined as follows.

$$
\begin{gathered}
W_{N, T}^{H n c}=\frac{1}{N} \sum_{i=1}^{N} W_{i, T} \\
\bar{Z}_{N, T}^{H n c}=\sqrt{\frac{N}{2 K}}\left(W_{N, T}^{H n c}-K\right)
\end{gathered}
$$

$W_{i, T}$ denotes the individual Wald statistics for the individual cross-section units. According to the Monte Carlo experiments of Dumitrescu and Hurlin (2012), this procedure has very good small sample properties and robust to cross-sectional dependence. This study employs Dumitrescu and Hurlin (2012) heterogeneous panel causality analysis and Table 7 presents the results. 
Table 7. The Results of Heterogenous Causality Analyses

\begin{tabular}{|c|c|c|c|c|c|c|}
\hline Region & Null Hypothesis & $\begin{array}{c}\text { W } \\
\text { Statistic }\end{array}$ & $\begin{array}{c}\overline{\bar{Z}} \\
\text { Statistic }\end{array}$ & Probability & $\begin{array}{c}\text { Optimal } \\
\text { Lag }\end{array}$ & Conclusion \\
\hline \multirow{2}{*}{ Eastern } & $\ln E N \rightarrow \ln G D P$ & 90.0151 & $66.5602 * * *$ & 0.0000 & 7 & \multirow{2}{*}{$\begin{array}{l}\text { Bidirectional } \\
\text { causality }\end{array}$} \\
\hline & $\ln G D P \rightarrow \ln E N$ & 8.1974 & $15.2681 * * *$ & 0.0000 & 1 & \\
\hline \multirow{2}{*}{ Middle } & $\ln E N \rightarrow \ln G D P$ & 205.587 & $91.9286 * * *$ & 0.0000 & 7 & \multirow{2}{*}{$\begin{array}{l}\text { Bidirectional } \\
\text { causality }\end{array}$} \\
\hline & $\ln G D P \rightarrow \ln E N$ & 253.661 & $114.182 * * *$ & 0.0000 & 7 & \\
\hline \multirow{2}{*}{ North } & $\ln E N \rightarrow \ln G D P$ & 1.9027 & $1.6888 *$ & 0.0913 & 1 & \multirow{2}{*}{$\begin{array}{l}\text { Bidirectional } \\
\text { causality }\end{array}$} \\
\hline & $\ln G D P \rightarrow \ln E N$ & 3.3554 & $4.4065 * * *$ & 0.0000 & 1 & \\
\hline \multirow{2}{*}{ South } & $\ln E N \rightarrow \ln G D P$ & 2.8677 & $3.9620 * * *$ & 0.0000 & 1 & \multirow{4}{*}{$\begin{array}{l}\text { Bidirectional } \\
\text { causality } \\
\text { Unidirectional } \\
\text { causality from } \\
\ln E N \text { to } \ln G D P\end{array}$} \\
\hline & $\ln G D P \rightarrow \ln E N$ & 3.3561 & $4.9981 * * *$ & 0.0000 & 1 & \\
\hline \multirow{2}{*}{ Western } & $\ln E N \rightarrow \ln G D P$ & 2.2758 & $2.3869 * * *$ & 0.0000 & 1 & \\
\hline & $\ln G D P \rightarrow \ln E N$ & 1.4471 & 0.8364 & 0.4029 & 1 & \\
\hline
\end{tabular}

Notes: (i) $\ln E N$ indicates the logarithmic energy consumption whereas $\ln G D P$ indicates the logarithmic GDP per capita. (ii) * and $* * *$ denote the statistical significance at $90 \%$ and $99 \%$ levels, respectively. (iii) Lags criterion decision is based on Akaike Information Criterion from 1 to 9.

Table 7 shows that there is bidirectional causality between logarithmic energy consumption and logarithmic GDP per capita for Eastern, Middle, North, and South European regions whereas there is unidirectional causality from logarithmic energy consumption logarithmic GDP per capita for the Western European region.

Parallel to the other studies in the literature that examine the other continents (e.g., Ali, 2018; Fatai, 2014; Usman, 2020; Yu and Meng, 2008), the findings indicate that the relationship based on causality between primary energy consumption and economic growth differs by the regions in the European continent. The results indicate a bidirectional causality between the primary energy consumption and the economic growth for the Eastern, Middle, North, and South European regions. This result is consistent with the findings of the studies analyzed in the second section for Thailand, the Philippines, Nigeria, the United States, and the middle-income countries. Furthermore, another study for Portugal, Italy, Greece, Spain, and Turkey indicates a bidirectional relationship as well (Fuinhas and Marques, 2012). Unlike the other regions, Western European region countries have a unidirectional causal relationship from primary energy consumption to economic growth. The previous studies in the second section indicate a unidirectional relationship between energy consumption and economic growth in Indonesia, China, and Brazil as well.

\section{Conclusion and Discussion}

The consumption of primary and secondary energy in the production process and the impact of this consumption on economic growth are important topics in the energy economics literature. This study analyses the relationship between non-renewable i.e., primary energy consumption and economic growth in European continent by regions.

The results of empirical analyses provide evidence about there are bidirectional causality between non-renewable energy consumption and economic growth in Eastern, Middle, North, and South European regions. Non-renewable energy consumption and economic growth are still interconnected even though climate concerns, environmental precautions, and promotion to reduce sustainable production, non-renewable energy resources. However, there is 
unidirectional relationship from non-renewable energy consumption to economic growth in the Western European countries. The Western European countries has the highest welfare level and second most non-renewable energy consumption level among the other regions. Furthermore, Western European countries recently lower the non-renewable energy consumption levels. Therefore, one might say that the increase in welfare may help to have better environmentally friendly economic growth.

This study may help to emphasize the importance of impact of non-renewable energy consumption on economic growth as well as the impact of economic growth on non-renewable energy consumption. Although many scientific studies, international negotiations, agreements, and protocol promotes the less non-renewable energy consumption, the results shows that the consumption of non-renewable energy consumption is still has a significant effect on economic growth on every region of European continent. However, increase of renewable energy resources and consumption may provide economies a significant and sustainable advantage. Furthermore, increase of renewable energy consumption has less air, water, and soil pollution, and therefore protects the renewable property of environment. As the many studies support, increasing the consumption of renewable energy may have an impact on sustainable economic growth in the long run.

\section{Researchers' Contribution Rate Statement}

The authors declare that they have contributed equally to the article.

\section{Conflict of Interest Statement}

There is no potential conflict of interest in this study. 


\section{References}

Adhikari, D. and Chen, Y. (2013). Energy consumption and economic growth: A panel cointegration analysis for developing countries. Review of Economics \& Finance, 3(2), 68-80. Retrieved from http://www.bapress.ca/

Akadiri, S. S. and Akadiri, A. C. (2020). Interaction between CO2 emissions, energy consumption and economic growth in the Middle East: Panel causality evidence. International Journal of Energy Technology and Policy, 16(2), 105-118. https://doi.org/10.1504/IJETP.2020.105507

Ang, J. (2008). Economic development, pollutant emissions and energy consumption in Malaysia. Journal of Policy Modelling, (30), 271-278. https://doi.org/10.1016/j.jpolmod.2007.04.010

Apergis, N. and Payne, J. (2009). Energy consumption and economic growth in Central America: Evidence from a panel cointegration and error correction model. Energy Economics, 31(2), 211216. https://doi.org/10.1016/j.eneco.2008.09.002

Asafu-Adjaye, J. (2000). The relationship between energy consumption, energy prices and economic growth: Time series evidence from Asian developing countries. Energy Economics, 22, 615-625. https://doi.org/10.1016/S0140-9883(00)00050-5

Breitung, J. (2000). The local power of some unit root tests for panel data. In B. H. Baltagi (Ed.), Nonstationary panels, panel cointegration and dynamic panels (pp. 161-177). Amsterdam: Elsevier.

Cevik, E. I., Yıldırım, D. Ç. and Dibooglu, S. (2020) Renewable and non-renewable energy consumption and economic growth in the US: A Markov-Switching VAR analysis. Energy \& Environment, 123. doi:10.1177/0958305X20944035

Chaudhry, I., Sadfar, N. and Farooq, F. (2012). Energy consumption and economic growth: Empirical evidence from Pakistan. Pakistan Journal of Social Sciences, 32(2), 371-382. https://doi.org/10.1007/s11135-011-9468-3

Choi, I. (2001). Unit root tests for panel data. Journal of International Money and Finance, 20(2), 249272. https://doi.org/10.1016/S0261-5606(00)00048-6

Demirel, Y. (2012). Energy: Production, conversion, storage, conservation, and coupling (Green energy and technology). London: Springer-Verlag.

Dogan, E. and Seker, F. (2016). Determinants of CO2 emissions in the European Union: The role of renewable and non-renewable energy. Renewable Energy, 94, 429-439. https://doi.org/10.1016/j.renene.2016.03.078

Dumitrescu, E. and Hurlin, C. (2012). Testing for Granger non-causality in heterogeneous panels. Economic Modelling, 1450-1460. https://doi.org/10.1016/j.econmod.2012.02.014

Fatai, B. O. (2014). Energy consumption and economic growth nexus: Panel co-integration and causality tests for Sub-Saharan Africa. Journal of Energy in Southern Africa, 25(4), 93-100. https://doi.org/10.17159/2413-3051/2014/v25i4a2242

Fuinhas, J. and Marques, A. (2012). Energy consumption and economic growth nexus in Portugal, Italy, Greece, Spain, and Turkey: An ARDL bounds test approach. Energy Economics, 34(2), 511-517. https://doi.org/10.1016/j.eneco.2011.10.003

Gozgor G., Lau, C. and Lu, Z. (2018). Energy consumption and economic growth: New evidence from the OECD countries. Energy, 153, 27-34. https://doi.org/10.1016/j.energy.2018.03.158

Hadri, K. (2000). Testing for stationarity in heterogeneous panel data. Econometrics Journal, 3, 148-161. https://doi.org/10.1111/1368-423X.00043

Harris, R. and Tzavalis, E. (1999). Inference for unit roots in dynamic panels where the time dimension is fixed. Journal of Econometrics, 91, 201-226. https://doi.org/10.1016/S0304-4076(98)00076-1

Im, K., Lee, J. and Tieslau, M. (2005). Panel LM unit-root tests with level shifts. Oxford Bulletin of Economics and Statistics, 393-419. https://doi.org/10.1111/j.1468-0084.2005.00125.X 
M. Y1lgör, S. Korkmaz \& F. Kömüryakan, “The Relationship between Non-Renewable Energy

Consumption and Economic Growth: A Regional Analysis of European Continent"

Im, K., Lee, J. and Tieslau, M. (2010). Panel LM unit root tests with trend shifts (FDIC Center for Financial Research Working Paper, No. 2010-1). http://dx.doi.org/10.2139/ssrn.1619918

Im, K., Pesaran, M. and Shin, Y. (2003). Testing for unit roots in heterogeneous panels. Journal of Econometrics, 115(1), 53-75. https://doi.org/10.1016/S0304-4076(03)00092-7

Khan, M. T. I., Yaseen, M. R. and Ali, Q. (2018). The dependency analysis between energy consumption, sanitation, forest area, financial development, and greenhouse gas: A continent-wise comparison of lower middle-income countries. Environmental Science and Pollution Research, 25(24), 2401324040. https://doi.org/10.1007/s11356-018-2460-x

Lee, J. and Strazicich, M. (2003). Minimum LM unit root test with two structural breaks. Review of Economics and Statistics, 1082-1089. https:// doi.org/10.1162/003465303772815961

Lee, J. and Strazicich, M. (2004). Minimum LM unit root test with one structural break (Appalachian State University Working Papers). Retrieved from https://econpapers.repec.org/

Levin, A., Lin, C. and Chu, C. (2002). Unit root tests in panel data: Asymptotic and finite-sample properties. Journal of Econometrics, 108, 1-24. https://doi.org/10.1016/S0304-4076(01)00098-7

Mehrara, M. (2007). Energy consumption and economic growth: The case of oil exporting countries. Energy Policy, 35, 2939-2945. https://doi.org/10.1016/j.enpol.2006.10.018

Muse, B. O. (2014). Energy consumption and economic growth in Nigeria: Correlation or causality?. Journal of Empirical Economics, 3(3), 108-120. Retrieved from https://ideas.repec.org/

$\mathrm{Ng}$, S. and Perron, P. (1995). Unit root tests in ARMA models with data-dependent methods for the selection of the truncation lag. Journal of the American Statistical Association, 90, 269-281. https://doi.org/10.1080/01621459.1995.10476510

Ozturk, I., Aslan, A. and Kalyoncu, H. (2010). Energy consumption and economic growth relationship: Evidence from panel data for low- and middle-income countries. Energy Policy, 38(8), 4422-4428. https://doi.org/10.1016/j.enpol.2010.03.071

Pao, H., Li, Y. and Fu, H. (2014). Causality relationship between energy consumption and economic growth in Brazil. Smart Grid and Renewable Energy, 5, 198-205. https://doi.org/10.4236/sgre.2014.58019

Paul, S. and Bhattacharya, R. (2004). Causality between energy consumption and economic growth in India: A note on conflicting results. Energy Economics, 26(6), 977-983. https://doi.org/10.1016/j.eneco.2004.07.002

Perron, P. (1989). The great cash, the oil price shock, and the unit root hypothesis. Econometrica, 13611401. https://doi.org/10.2307/1913712

Pesaran, M. H. (2003). A simple panel unit root test in the presence of cross section dependence (Cambridge Working Papers in Economics No. 0346). http://dx.doi.org/10.2139/ssrn.457280

Pesaran, M. H. (2004). General diagnostic tests for cross section dependence in panels (IZA Discussion Paper No. 1240). https://doi.org/10.17863/CAM.5113

Swamy, P. (1970). Efficient inference in a random coefficient regression model. Econometrica, 38(2), 311-323. https://doi.org/10.2307/1913012

Usman, M., Kousar, R., Yaseen, M. R., and Makhdum, M. S. A. (2020). An empirical nexus between economic growth, energy utilization, trade policy, and ecological footprint: A continent-wise comparison in upper-middle-income countries. Environmental Science and Pollution Research, 27(31), 38995-39018. https://doi.org/10.1007/s11356-020-09772-3

Yu, Q. H. and Meng, W. D. (2008). The relationship between energy consumption and Chinese economic growth based on panel data. Systems Engineering, 26, 68-72. Retrieved from https://en.cnki.com.cn/

Zhang, X.-P. and Cheng, X.-M. (2009). Energy consumption, carbon emissions, and economic growth in China. Ecological Economics, 68(10), 2706-2712. https://doi.org/10.1016/j.ecolecon.2009.05.011 
Ekonomi, Politika \& Finans Araştırmaları Dergisi, 2021, 6(3): 587-607

Journal of Research in Economics, Politics \& Finance, 2021, 6(3): 587-607

Zivot, E. and Andrews, D. (1992). Further evidence on the great crash, the oil-price shock, and the unitroot hypothesis. Journal of Business and Economic Statistics, 11, 251-270. https://doi.org/10.2307/1391541 